Turkish Online Journal of Qualitative Inquiry (TOJQI)

Volume 10, Issue 4, October 2019: 409-438

DOI: $10.17569 /$ tojqi.602958

Research Article

\title{
Opinions of Scholars on the 2018 Social Studies Teacher Training Program ${ }^{1}$
}

\author{
Hilal Şarpal ${ }^{2}$, İsmail Acun ${ }^{3}$
}

\begin{abstract}
The aim of the research was to investigate the 2018 social studies teacher training curriculum and evaluate it within the framework of lecturers' opinions. This research employs a qualitative research approach. Within the scope of this research, documents related to the topic were investigated and semi-structured interviews were held with participants attending workshops during the development process of the revised program with the aim of confirming data obtained from the documents. Questions related to problems in the data obtained from documents and interviews were analyzed with descriptive and content analysis techniques together to obtain answers. The research findings revealed the changes to the revised social studies teacher training program curriculum encompass only the content dimension in the program development process. Data obtained from interviews with lecturers contributing to the preparation of the curriculum support this finding. This study reveals that the difficulties that occurs during implementation of old curriculum will persist during the implementation process for the 2018 social studies teacher training program.
\end{abstract}

Keywords: Social studies teaching, social studies, program assessment, curriculum

\footnotetext{
${ }^{1}$ This study was drawn from the data collected for the master's thesis carried out by Hilal Şarpal under the supervision of Ismail Acun for the fulfillment of the requirement of ESOGU, Institute of Education, 2018. A small part of the data is presented in UCEK, 2019.

${ }^{2}$ Graduate Student, egitim.hilal@ gmail.com, https://orcid.org/0000-0002-0011-2657

${ }^{3}$ Assoc. Prof. Dr., Usak University, Faculty of Education, Department of Social Studies Education, ismail.acun@usak.edu.tr, https://orcid.org/0000-0003-1248-1836
}

Received: 07.08.2019, Accepted: 25.10.2019 


\title{
2018 Yılı Sosyal Bilgiler Öğretmenliği Öğretim Programı Hakkında Öğretim Üyelerinin Görüşleri
}

\begin{abstract}
$\ddot{\mathbf{O z}}$
$\mathrm{Bu}$ araştırmanın amacı, 2018 yılı sosyal bilgiler öğretmenliği öğretim programını incelemek ve öğretim üyelerinin görüşleri çerçevesinde değerlendirmektir. 2018 yılı sosyal bilgiler öğretmenliği öğretim programının incelendiği bu araştırma da nitel araştırma yöntemi kullanılmıştır. $\mathrm{Bu}$ araştırma kapsamında konu ile ilgili dokümanlar incelenmiş ve dokümanlardan elde edilen verilerin teyit edilmesi amaciyla güncellenen programın geliştirilme sürecinde yapılan çalıştaylara katılarak görüş bildiren katılımcılarla yarı yapılandırılmış görüşmeler gerçekleştirilmiştir. Dokümanlardan ve görüşmelerden elde edilen veriler problem durumunda yer alan sorulara cevap alınacak şekilde betimsel ve içerik analizi tekniklerinin birlikte kullanılmasıyla çözümlenmiştir. Araştırma bulguları, güncellenen sosyal bilgiler öğretmenliği öğretim programında yapılan değişikliklerin, program geliştirme süreçlerinin bir boyutu olan içerik boyutunu kapsadığını ortaya koymaktadır. Programın hazırlanmasına katkı sağlayan öğretim üyeleriyle yapılan görüşmelerden elde edilen veriler de bu bulguyu destekler niteliktedir. Bu çalışma, kuramsal olarak zengin bir içeriğe sahip gibi görünen 2018 yılı sosyal bilgiler öğretmenliği öğretim programının uygulanma sürecinde var olan aksaklıkların devam edeceğini ortaya koymaktadır.
\end{abstract}

Anahtar Sözcükler: Sosyal bilgiler ögretmenliği, sosyal bilgiler, program değerlendirme, ögretim programı 


\section{Introduction}

Operation of the educational system as desired is linked to students, teachers and the curriculum being compatible (Şimşek, 2017). The "teachers" can be said to be the most important element of the education system as it is their duty to cultivate students compatible with the curriculum (Azar, 2011). Training teachers with qualities to ensure completion of the curriculum targets is a topic of sensitive focus for all countries (Çelikten, Şanal, \& Yeni, 2005). This situation has led to a variety of reorganizations of teacher training programs from the past to the present (Akdemir, 2013).

\section{MoNE (MEB) Social Studies Curriculum}

In Turkey, "history", "geography" and "civic education" were taught as separate subjects from 1926 to 1962 and then combined under the name "society and country investigations" in 1962. From this date, though social studies was sometimes used in the country, the term studies appeared officially in 1968. From 1975, social studies began to be used in all middle schools and in 1985 it was split into 3 separate subjects of "national history", "national geography" and "citizenship education". In 1997 the "national history" and "national geography" subjects were removed from the curriculum, and in 1998 they were placed in the social studies curriculum encompassing $4^{\text {th }}$ and $7^{\text {th }}$ grades (K1lınçkaya, 2018).

In 2004, the aims of the social studies were dealt with in two tiers; as universal and national targets. Students gaining competence in a variety of social studies areas like history, geography, economy and sociology are among the universal aims of the program ensuring continuation of society (Öztürk, 2012). National aims somehow different from universal aims also aims to re-cultivation and continuations of the society. Social studies plays a crucial role in terms of ensuring students know their basic rights and duties as democratic individuals and can make correct decisions based on common sense when they encounter problems (Akdağ, 2008).

Based on the constructivist approach, in 2004 the aim of the social studies curriculum was not to load students with information but for them to gain the skill of being able to produce information (Artvinli, 2010). Skills are the individual's expected ability to transfer 
attainments and gains from the learning process into their own lives (İnci, 2009). Attainment of skills determined in the curriculum by students is the duty of the teacher (Hayırsever, 2010). In the social studies curriculum, it appears the skills that students are expected to attain are clearly stated (Kabapinar, 2014).

One of the targets of the social studies is to contribute to the students' moral development and positively shape their character. This situation can only occur with good values education (Akbaş, 2008). For individuals to effectively take their place in society and to display attitudes sensitive to the expectations of society, the importance of values education is great (Özdaş, 2013). For students to attain the values included on the curriculum, it is necessary for schools and families to cooperate (Acun, Yücel, Önder, \& Tarman, 2013).

\section{Social Studies Teacher Competencies}

The competencies of teachers to be able to carry out their duties and responsibilities in their professional field are the knowledge, skills and values (Gökçe, 1999). A teacher's possession of these competencies is linked to the quality of education that they received in the teacher training institutions (Kutluca, Birgin, \& Çatlığlu, 2007).

Before social studies teachers begin a lesson, first they have to plan the lesson in advance. It is beneficial to the learning and teaching processes that lessons are operate with a plan. The expected behavior from a qualified teacher is that before lessons they organize to lesson from the aspect of examples to be given in lessons, information to be presented and activities to be carried out (Kiziltepe, 2002). Teachers should be able to effectively manage the learning and teaching processes (Öztürk, 2009). A rote education carried out in teacher training institutions and/or by the social studies teachers themselves ends up not being able to teach necessary skills to the students. The fact that social studies teachers may not have encountered the activities required to be implemented during lessons in the preservice period may represent a problem in terms of operating the learning and teaching processes (Korkmaz, 2009).

Education is the process of realizing the expected change in the behavior of the individual. Control of this process is through determining the success, measurement and evaluation of the students in terms of the behavior change expected (Şenyurt, 2016). A variety of measurement and evaluation techniques are used while attaining the knowledge, skills and values included 
on the social studies curriculum. During social studies lesson teaching a great care should be taken that the measurement and evaluation approach adopted for this lesson take note of individual differences, considering that every individual has different levels of learning knowledge, implementing skills and obtaining values (İnci, 2009).

In the learning process, the effects of the family, school and environment on the student are immense. The most important thing is that school and family act in cooperation (Gülcan \& Taner, 2011). With regard to cooperation between school, family and society, the teacher's leadership qualities come to the fore. The teacher should be in a guiding position within the school and class. In fact, one of the teacher's duties is to enlighten society. For this, the teacher should be someone with exemplary characteristics and should guide those around them (Çelikten, Şanal; \& Yeni, 2005).

Teachers' attitudes toward their profession affect their professional success, just as they have an important place in education and teaching activities (Can, 2013). However, a teacher who knows and loves his/her profession will expend efforts to ensure personal and professional development. Social studies teachers should follow developments in their own field and be open to innovative ideas. At the same time, teachers should attend conferences and seminars to develop themselves and contribute to development of their field. With the aim of contributing to developments in the field, teachers are expected to research at academic level and should know at least one foreign language to the level of speaking and writing (MEB, 2017).

\section{Teacher Training in Turkey}

Since the 1800s, teaching has been accepted as a profession in many countries. In our country, the teacher training tradition extends to the Ottoman period (Çelik \& Gündoğdu, 2007). In 1840, it was decided that teachers needed to undergo special education in order to perform the requirements of the profession. In line with this aim, schools to train teachers were opened in 1848. The first teaching school opened by the Ottomans with the aim of training teachers was 'darülmuallimin' (Duman, 2009).

Since the Republican period, significant developments were experienced in the education and teaching system (Kavcar, 2002). In 1940, Village Institutes “Köy Enstitüleri” with an 
important place in development of society in terms of economic, cultural and social aspects were opened. The Village Institutes, with contributions not just to training teachers but also to training other professional personnel, were abolished in 1954 (Kartal, 2008). In 1974, all teaching schools were combined under the name "teaching high schools" (Saç, 2016). Until 1982, teachers were trained under the guidance of the Ministry of National Education (MEB). From this date, the responsibility of training teachers passed to universities (Y1lmaz, 2005). Since the 1990s, many studies have been performed to improve the teacher training system (Koçak \& Kavak, 2014).

In recent years in Turkey, comprehensive changes were made to teacher training programs twice. The first of these changes was restructuring of faculties of education in 1997 due to problems in teacher training implementation continuing until 1996 (Azar, 2011). The second change occurred with the reorganization of teacher training programs in 2006-2007 due to changes made to the teacher training program in 1997 being seen as insufficient (Demir, 2012). The most recent update to teacher training programs occurred in 2018 with the aim of training teachers in accordance with the requirements of the current age. This study was completed on the revised social studies teacher training program curriculum. The results of this research are considered to illuminate future studies to be performed about the social studies teacher training curriculum. The reason for this is the continuity involved in the need to update teacher curricula in accordance with the requirements of the modern era.

To understand how and in what ways the social studies teacher training program was revised in 2018 changed compared to the previous curriculum, the answers to the following questions were sought during this research;

- When evaluated with the established curriculum development and evaluation practices, how is the new social studies teacher training program?

- What are the similarities and differences between the 2018 social studies teacher training program and the previous one?

- What is the education and teaching process envisaged by the 2018 social studies teacher training program?

- What is the measurement and evaluation process envisaged in the 2018 social studies teacher training program? 
- In terms of competencies of preservice teachers for lessons, to what extent is the 2018 social studies teacher training program associated with topics in the primary and middle school social studies lessons?

- To what extent do lessons included on the 2018 social studies teachers training curriculum fulfill the competencies envisaged in the framework of social studies teachers' competencies?

\section{Method}

\section{Research Design}

A qualitative research approach was used in this research. Qualitative research is a research type using techniques like observation, interviews and document analysis with the aim of collecting in-depth information about a topic (Yıldırım, 1999). In this research, interviews were held with experts and the 2018 social studies teacher training program curriculum was investigated in light of data obtained from the interviews.

\section{Participants}

The study group in this research comprised of 11 lecturers contributing to preparation of the 2018 social studies teacher training curriculum. Information about the demographic characteristics of the lecturers are given in Table 1.

Table 1

Demographic Characteristics of Lecture Staff

\begin{tabular}{llll} 
& Sex & Title & Organization \\
\hline LS1 & Female & Professor & Central Anatolia \\
LS 2 & Female & Associate Professor & Central Anatolia \\
LS 3 & Male & Professor & Central Anatolia \\
LS 4 & Male & Professor & Central Anatolia \\
LS 5 & Male & Doctor Lecturer & Central Anatolia \\
LS 6 & Male & Professor & Marmara \\
LS 7 & Male & Associate Professor & Aegean \\
LS 8 & Male & Associate Professor & Mediterranean \\
LS 9 & Male & Associate Professor & Black Sea \\
LS 10 & Male & Associate Professor & Central Anatolia \\
LS 11 & Male & Professor & Mediterranean \\
\hline
\end{tabular}


In this research, with the purpose of collecting the necessary, data, criterion sampling method was chosen. In this method used in qualitative research, the researcher may choose a sample to study of anyone who is appropriate for the research topic (Koçak \& Arun, 2006). In line with the aims, the selection criteria for participants were;

- Working in a social studies teacher training department,

- Having professional experience to evaluate both the old and new curricula,

- Participating in at least one of the preparation studies for the 2018 curriculum.

Additionally, lecturers who specialized in separate branches that were close to social studies, like history education or geography education, and who worked as administrators in education faculties or education science institutes were accepted as advantageous in terms of variety.

\section{Data Collection Tools}

The data sources in this research were documents and data obtained from semi-structured interviews. Within this framework, with the aim of investigating the 2018 social studies teacher training program documents belonging to old and new curricula were investigated within the framework of teacher competencies and semi-structured interviews were held with lecturers who contributed to preparation of the curriculum. Questions on the interview form were prepared by the researcher in such a way as to answer the research questions. For the validity of the questions, 3 experts including an associate professor in the social studies education field, a doctor lecturer in the education curriculum and teaching field, and a professor in the education management field evaluated the questions before they were given their final form.

The interview form included 13 questions to collect information about the philosophy, aim, education and teaching process, and measurement and assessment process forming the basis of the curriculum development process. Scholars who participated in the curriculum development process were asked questions such as what the philosophy of the curriculum is, and what is vision of the program the education and teaching process. 


\section{Research Process}

The researcher collected data during one-to-one interviews by going to the organization where the lecturers were employed or through social media. The interview durations varied from 30 to 60 minutes. Interviews were recorded with a voice recording device and transcribed. Participants voluntarily participated in the research and the responses that participants gave to questions asked in the interview were kept anonymous due to ethical considirations. As a result, the names of the lecture staff in the study were coded as "LS1,LS2,LS3,LS4, LS5, LS6, LS7, LS8, LS9, LS10 and LS11".

\section{Data Analysis}

Data obtained about the revised curriculum were descriptively investigated to answer research questions of the study based on the Taba-Tyler model used for curriculum development and investigation processes. During analysis of data, very rich content was reached from data obtained in interviews, especially. In the second stage of data analysis, it was decided that the use of content analysis would be more appropriate. According to Patton and Silverman, the process targeting revelations about the relationship of data obtained in research with each other is called content analysis (cited from 2005, Çelik, 2011). Transcripts were read within this framework and open codes were created. These codes were compared with codes and categories used in descriptive analysis. Additionally, for suitability of codes and categories, they were evaluated for whether there was consensus between coders or not (inter-rater reliability was not calculated using a formula). In the final stage, data were analyzed according to both the determined theoretical framework (e.g., Taba-Tyler model, basic concepts in competency framework) and the codes and categories obtained from data.

\section{Results}

In this section, the study findings are given in light of codes created based on data obtained from document analysis and interviews with lecturers participating in the curriculum development process with the aim of investigating the 2018 social studies teacher training program. Analyses in this section are based 'the teacher competencies' and 'middle school social studies curricula' documents of the Council of Higher Education (YÖK 2018) and 
MEB (2018) and (2017) respectively. The documents will be not cited and referred as the documents hereafter.

Findings About the Development Process for the 2018 Social Studies Teacher Training Program

Based on data obtained from interviews with lecturers, the codes of 'analysis of needs', 'planning', 'data-based', 'stakeholder opinions', 'scientific', 'pilot implementation' and 'evaluation' were created under the category of 'curriculum development processes'.

Lecturers were observed to report that sufficient analysis of needs was not performed during preparation of the social studies teacher training curriculum, as a result there was no information about whether the curriculum required an update and they had doubts that the revised program would correct problematic aspects of the old program. In terms of representing the opinions of participants related to this topic, the opinions of participant coded LS9 were as follows;

"When evaluating the curriculum, analysis of needs of all stakeholders in Turkey
should be performed, with opinions obtained but these opinions don't have to be
given in workshops all the time and not every province has a workshop, there are
different methods. This analysis needs to be performed really well. This analysis
was not done well, deficiencies in the curriculum were not identified well and
because they were not identified well, I think this curriculum is not at the level to
meet the requirements." (LS9, 14'20")

Lecturers participating in the curriculum development process stated more than one meeting was held in the curriculum development process and that different opinions were used. However, lecturers attending these meetings saw a problem due to not being able to participate in later meetings. The reason for this problem was seen to be due to different lecturers working on the same text in every meeting. In terms of representing the opinions of participants about this topic, LS6 participant expressed the following views;

"Different teams worked on the same text. As a result, this was a good thing from one aspect because different opinions were obtained, but on the other hand we encountered this one of the meetings I attended, we couldn't understand the earlier logic and because we didn't know some things seemed really strange to us. There was no chance to discuss it." (LS6, 00'44") 
The curriculum development process beginning with identification of needs should then have pilot implementation studies performed to check the changes to the curriculum and evaluate the results obtained (Demirel, 2007). One lecturer drew attention to the implementation and evaluation stages of the revised social studies teacher training curriculum development process;

"I think curriculum development studies were not very sufficient. Also, instead of immediately implementing the developed curriculum performing a pilot implementation trying it in a few universities is needed to measure the outcomes. There was no such pilot study performed" (LS2, 03'31").

Based on this opinion, though lecturers know that pilot studies are an important stage in the curriculum development process, it was concluded that sufficient importance was not attached to this stage in the social social studies teacher training curriculum development process.

\section{Findings About Similarities and Differences Between the 2018 Social Studies Teacher Training Program Curriculum with Previous One}

When the revised social studies teacher training curriculum is investigated, it appears only lesson titles and contents were included. With the aim of being able to investigate the content of the 2018 social studies teacher training curriculum, when analyzing data in the 'content' category the following codes were created; 'name changes', 'removed from curriculum', 'credit changes', 'added to curriculum', 'elective lessons' and 'applied lessons'.

Table 2

Findings about Lessons in the Social Studies Teacher Training Curriculum

\begin{tabular}{llll}
\hline Type of lesson & Lessons removed from curriculum & Lesson credit & $\begin{array}{l}\text { Lesson } \\
\text { semester }\end{array}$ \\
\hline \multirow{4}{*}{ Area training } & Archeology & $\mathrm{T}+2$ & $\mathrm{I}$. \\
& Sociology & $\mathrm{T}+2$ & $\mathrm{I}$. \\
& Social Psychology & $\mathrm{T}+2$ & $\mathrm{I}$. \\
& Ancient History and Civilizations & $\mathrm{T}+2$ & II. \\
& Philosophy & $\mathrm{T}+2$ & II. \\
& Economics & $\mathrm{T}+2$ & II. \\
& Basic Law & $\mathrm{T}+2$ & III. \\
& Geography of Countries & $\mathrm{T}+2$ & III. \\
& Contemporary World History & $\mathrm{T}+2$ & V. \\
& Human relationships and & $\mathrm{T}+2$ & VI. \\
& & & VI.
\end{tabular}




\begin{tabular}{llll} 
& communication & & \\
& Current World Problems & $\mathrm{T}+2$ & VII. \\
& Social Project Development & $\mathrm{T}+2$ & VIII. \\
\hline $\begin{array}{l}\text { Occupational } \\
\text { knowledge }\end{array}$ & School Experience & $\mathrm{T}+\mathrm{U}+5$ & VII. \\
\hline
\end{tabular}

As seen on Table 2, one lecturer stated this opinion in relation to lessons removed from the social studies teacher training curriculum;

"The content doesn't reflect lessons in our field. For example, law and economy lessons were removed, there's no sociology or philosophy lessons but they've been changed to education philosophy and education sociology." (LS1, 10'22”).

One lecturer stated the following in relation to the removal of the "geography of countries" lesson;

"For example, geography of countries was removed. I cannot understand this; in other words, just when we need a global view of the world." (LS10, 09'07").

In relation to the removal of the 'school experience' lesson from the curriculum, one lecturer expressed the following idea;

"I think there should be a lesson like school experience in the $1^{\text {st }}$ semester. I see that as a deficiency. For one thing, you need to get to know the profession. In $1^{\text {st }}$ year you should get to know the profession. If the student isn't able to do it, they need to get out of the system immediately." (LS5, 07'50").

Table 3

Findings About Lessons with Credit Changes on the Social Studies Teacher Training Curriculum

\begin{tabular}{llll}
\hline Type of lesson & Lesson Name & Previous credit & New credit \\
\hline \multirow{5}{*}{ Area Education } & $\begin{array}{l}\text { General Physical } \\
\text { Geography } \\
\text { General Human and }\end{array}$ & 4 & 2 \\
& $\begin{array}{l}\text { Economic } \\
\text { Geography }\end{array}$ & 4 & 2 \\
& $\begin{array}{l}\text { History of the } \\
\text { Middle Ages }\end{array}$ & 4 & 2 \\
\hline General culture & $\begin{array}{l}\text { Foreign Language } \\
\text { Turkish Language } \\
\text { Information } \\
\text { Technologies }\end{array}$ & 3 & 2 \\
\hline $\begin{array}{l}\text { Occupational } \\
\text { knowledge }\end{array}$ & $\begin{array}{l}\text { Introduction to } \\
\text { Education }\end{array}$ & 3 & 3
\end{tabular}


Education

Psychology

Teaching Principles

and Methods

Measurement and

Assessment in

Education

Guidance in Schools
3

2

As seen on Table 3, one lecturer stated the following in relation to lessons with credit changes on the revised program;

"It is not possible to explain a general physical geography lesson in two hours. Explaining this much content in that many hours, I have a problem in relation to what we will explain. Because we have the habit of four hours of lessons. The same thing is valid for the general human geography lesson, it's lowered to two hours and explaining this will be very difficult again" (LS3, 03'20”).

Table 4

Findings About Lessons Added to the Social Studies Teacher Training Curriculum

\begin{tabular}{llll}
\hline Type of lesson & Lessons added to curriculum & Lesson credit & $\begin{array}{l}\text { Lesson } \\
\text { semester }\end{array}$ \\
\hline \multirow{4}{*}{ Area Education } & $\begin{array}{l}\text { Learning and Teaching Approaches } \\
\text { in Social Studies }\end{array}$ & $\mathrm{T}+2$ & III. \\
& History of First Turkish Islamic & $\mathrm{T}+2$ & III. \\
& States & $\mathrm{T}+2$ & IV. \\
& Social Studies Curricula & $\mathrm{T}+2$ & VII. \\
& Disasters and Disaster Management & VII. \\
& Art and Museum Education & $\mathrm{T}+2$ & VII. \\
& Media Literacy and Education & $\mathrm{T}+2$ & VIII. \\
Occupational & Character and Values Education & $\mathrm{T}+2$ & II. \\
Knowledge & Education Sociology & $\mathrm{T}+2$ & II. \\
\hline
\end{tabular}

As seen in Table 4, a lecturer made the following statement about lessons added to the revised program;

"You can't change very much by adding a lesson, firstly we need teachers who understand the lesson, who conceptualize it, know it and can teach it. We added the lesson, but how many people can teach this lesson. We have 60 social studies education departments. But how many lecturers can give a lesson called disaster education, similar for media literacy." (LS4, 24'26") 
Table 5

Findings About Elective Lessons Added in Place of Lessons Removed from the Social Studies Teacher Training Curriculum

\begin{tabular}{|c|c|c|}
\hline $\begin{array}{l}\text { Lesson removed from } \\
\text { curriculum }\end{array}$ & $\begin{array}{l}\text { Elective lessons added to } \\
\text { curriculum }\end{array}$ & Type of lesson added \\
\hline Economics & Economy and Innovation & General Culture \\
\hline $\begin{array}{l}\text { Human relationships and } \\
\text { communication }\end{array}$ & $\begin{array}{l}\text { Human Relationships and } \\
\text { Communication }\end{array}$ & General Culture \\
\hline Art and Esthetic & Art and Esthetic & General Culture \\
\hline Current World Problems & Current World Problems & Area Education \\
\hline Drama & $\begin{array}{l}\text { Drama in Social Studies } \\
\text { Teaching }\end{array}$ & Area Education \\
\hline Curriculum Development & $\begin{array}{l}\text { Curriculum Development in } \\
\text { Education }\end{array}$ & Area Education \\
\hline Basic Law & Turkish Legal System & Area Education \\
\hline
\end{tabular}

As given in Table 5, a lecturer stated the following in relation to the inclusion of previously mandatory lessons in the elective lesson group on the revised curriculum;

"In other words, lessons like art and esthetic, current world problems, it's right they are elective according to me, but I don't think that about this drama lesson. It's like this, the teaching profession is a stage art you see and the lesson where we can learn information about stage art is drama, according to me." (LS5, 11 '41")

Based on this opinion, it can be concluded that lecturers negatively evaluated the removal of the drama lesson from the curriculum.

\section{Findings About Education and Teaching Processes in 2018 Social Studies Teacher Training Curriculum}

When the revised social studies teacher training curriculum is investigated, there appears to be no information about how the education and teaching processes should be implemented. Based on data obtained from interviews with lecture staff who worked on the preparation of the social studies teacher training curriculum, codes and categories were created as shown in Figure 1. 


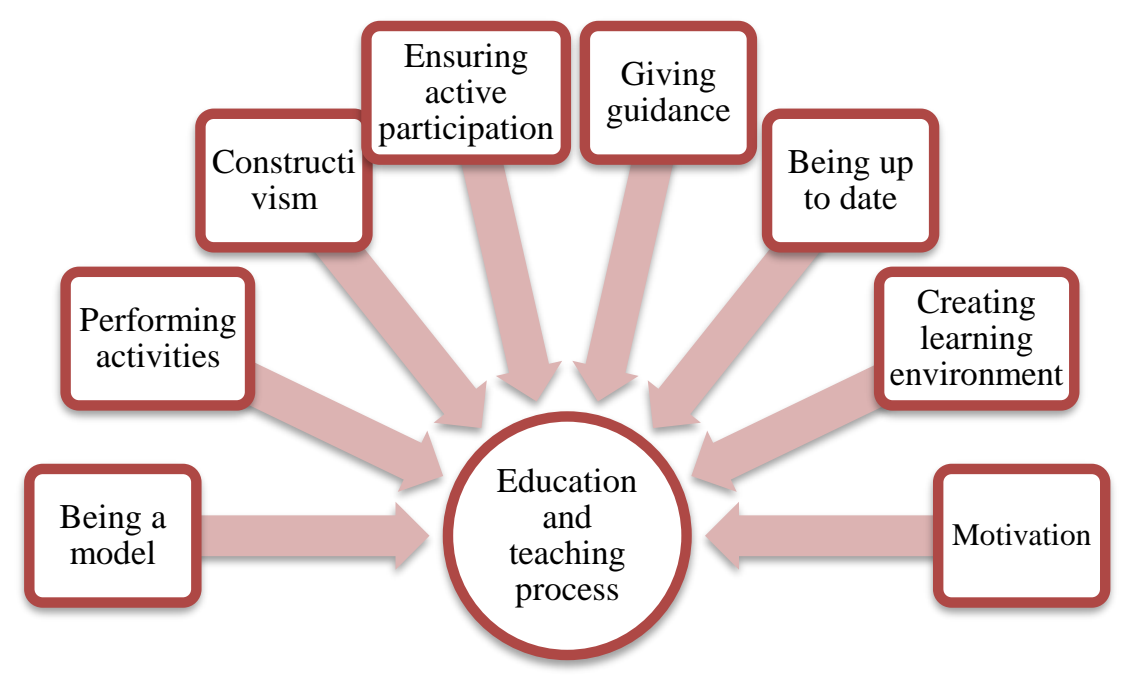

Figure 1. Codes Linked to "Education and Teaching Process" Category

Participants appeared to consider that as the 2004 social studies curricula were based on a constructivist teaching model, the education and teaching process in the social studies teacher training curriculum should include lessons operating in accordance with the constructivist teaching model. However, from responses given by lecturers to the interview questions it is understood that the constructivist teaching model was not realized in the implementation process for the curriculum. A lecturer stated the following in relation to this situation;

"The basic problem for preservice teachers is this, they told me one day; you want constructivist but we didn't see that in university. In other words, how can we apply something we haven't seen. As a result, if we complete activities with a constructivist approach in lessons here, maybe we can implement it." (LS2, 18 '40”)

Another situation affecting learning and teaching processes is the motivation of preservice teachers. Students with high motivation are more interested in learning compared to students with low motivation. Students with low motivation may also experience failure (Akbaba, 2006). Lecturers who worked on the social studies teacher training curriculum stated that the motivation of preservice teachers was low and as a result they were not interested in learning. One lecturer stated the following opinion in relation to this situation;

"We're not very good; in other words, we cannot give students high levels of knowledge, skills and equipment. Why can't we do this, students come all excited in $1^{\text {st }}$ year, in $2^{\text {nd }}$ year they become aware of the situation, and in $3^{\text {rd }}$ they're finished. They say; we came here but there's so many preservice teachers. If we can't be teachers, what will come from learning." (LS3, 34'48') 
To train highly skilled teachers during their preservice training, it is necessary that lecturers guide preservice teachers in the education and teaching process. In relation to this topic, participant coded LS5 stated the following which represents the opinions of the participants;

"Students come to learn something from you. They need your guidance. For 4 years before coming to every lesson I work. I feel I have to work over and over and I try to keep up to date." (LS5, 14'13")

Based on this opinion, it can be said that some lecturers try to act as mentors for preservice teachers in the education and teaching process.

In relation to how the education and teaching process should operate in the curriculum, participant coded LS1 stated the following opinion;

"Firstly, we need to be models. Teaching through modeling forms the basis of many concepts in fact. Whatever kind of teacher we want the preservice teachers to be in class, whether applying student-centered activities, developing material, being a constructivist teacher, including families in the process, implementing a variety of activities, having good communication, whatever kind of preservice teacher we want, we have to be that kind of teacher ourselves and we have to organize that kind of teaching environment." (LS1, 12'51')

Based on this opinion, it is understood that lecturers giving lessons about management of education and teaching processes have important responsibilities.

\section{Findings Related to Measurement and Assessment in the 2018 Social Studies Teacher Training Curriculum}

When the 2018 social studies teacher training curriculum is investigated, it appears there is no information about measurement and evaluation processes. A lecturer stated the following in relation to this situation;

"As the curriculum doesn't have a process dimension; in other words, taking a trip is left to the teacher's initiative, their conscience, bring them or not, if they do, they do it themselves. If they don't go, neither they nor the students go. I think the process will be affected completely by the teacher's qualities. Just looking at the lesson names or short content, we cannot say that the trained teacher will be this or that." (LS1, 20'57") 
As a result, it is concluded that rather than the structure of the revised curriculum affecting the quality of the preservice teachers at graduation, the quality of the lecturers giving the lessons will be an important factor.

\section{Findings about the relationship among 2018 social studies teacher training curriculum} and topics in primary and middle school social studies curricula

With the aim of determining findings about the relationship among the 2018 social studies teacher training curriculum and topics included in primary and middle school social studies curricula, the learning areas included on the social studies were coded as categories, while lesson content on the social studies teacher training curriculum associated with outcomes in these learning areas were coded linked to these categories.

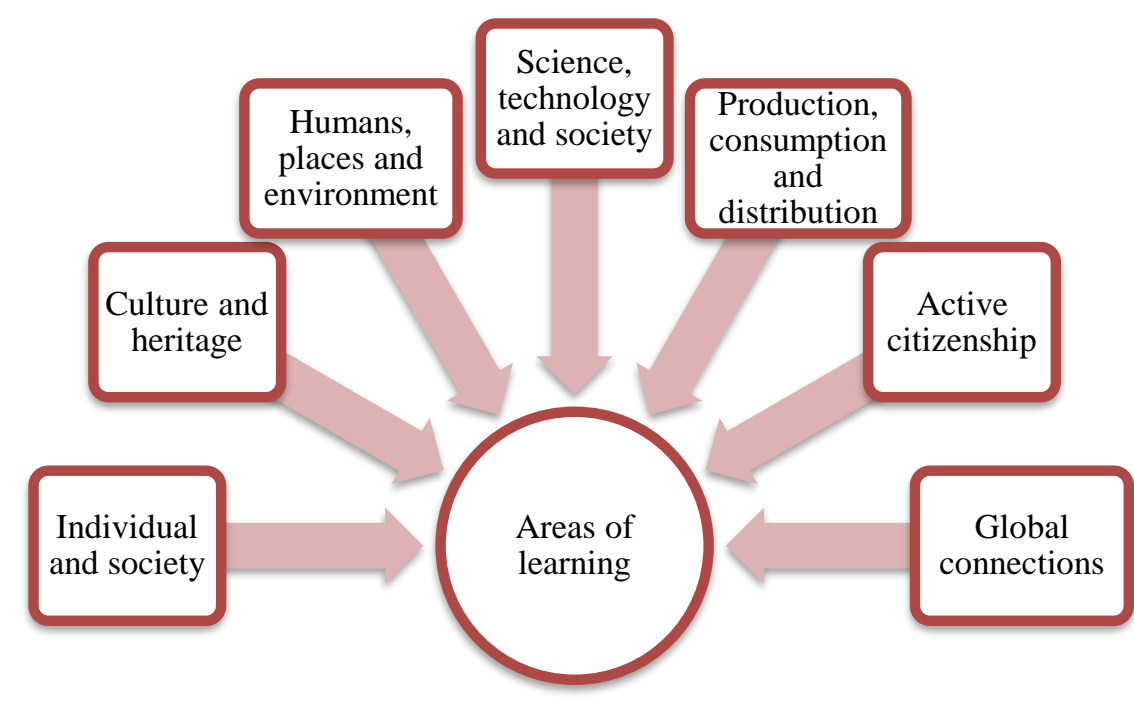

Figure 2. Subcategories Linked to the "Areas of Learning" Category

The subcategories linked to the 'learning areas' category are shown in Figure 2. With the removal of some education lessons which were mandatory in the 2006 curriculum, a lecturer considered this caused incompatibility with the MEB school curriculum;

"The teaching curriculum and the areas on the social studies education curriculum should overlap. In this sense, teachers who will teach the $4^{\text {th }}, 5^{\text {th }}, 6^{\text {th }}$ and $7^{\text {th }}$ class social studies, who will apply these, should take all lessons required by that curriculum. The removal of these, it's a bit like, I think it's a deficiency." (LS2, 06'04') 
Based on data obtained from interviews, lecturers included in the curriculum development process are understood to think the compliance between the MEB curriculum and the teacher training curriculum was not sufficiently examined. A lecturer who though this stated;

"In other words, we change the teacher training curriculum but the teachers we will train or do train, we don't look at the compatibility between changes to the curriculum the teachers will have to teach and our curriculum. That was not examined at all for example." (LS4, 22'59")

Table 5

Findings Related to Association of Learning Areas with Undergraduate Lessons

\begin{tabular}{|c|c|c|c|c|c|c|}
\hline $\begin{array}{l}\text { Individual and } \\
\text { Society }\end{array}$ & $\begin{array}{l}\text { Culture and } \\
\text { Heritage }\end{array}$ & $\begin{array}{l}\text { Humans, } \\
\text { places and } \\
\text { Environments }\end{array}$ & $\begin{array}{l}\text { Science, } \\
\text { technology } \\
\text { and society }\end{array}$ & $\begin{array}{l}\text { Production, } \\
\text { consumption } \\
\text { and } \\
\text { distribution }\end{array}$ & $\begin{array}{l}\text { Active } \\
\text { Citizenship }\end{array}$ & $\begin{array}{l}\text { Global } \\
\text { Connections }\end{array}$ \\
\hline $\begin{array}{l}\text { Social Studies } \\
\text { Teaching II }\end{array}$ & $\begin{array}{l}\text { Oral and } \\
\text { Written } \\
\text { Literature in } \\
\text { Social Studies }\end{array}$ & $\begin{array}{l}\text { General } \\
\text { Physical } \\
\text { Geography }\end{array}$ & $\begin{array}{l}\text { Science, } \\
\text { Technology } \\
\text { and Society }\end{array}$ & $\begin{array}{l}\text { General } \\
\text { Human and } \\
\text { Economic } \\
\text { Geography }\end{array}$ & $\begin{array}{l}\text { Human Rights } \\
\text { and } \\
\text { Democracy }\end{array}$ & $\begin{array}{l}\text { Political } \\
\text { Geography } \\
\text { and } \\
\text { Geopolitics of } \\
\text { Turkey }\end{array}$ \\
\hline $\begin{array}{l}\text { Education } \\
\text { Psychology }\end{array}$ & $\begin{array}{l}\text { Culture and } \\
\text { Language }\end{array}$ & $\begin{array}{l}\text { Physical } \\
\text { Geography of } \\
\text { Turkey }\end{array}$ & $\begin{array}{l}\text { Information } \\
\text { Technologies }\end{array}$ & $\begin{array}{l}\text { Economic } \\
\text { Structure of } \\
\text { Turkey }\end{array}$ & $\begin{array}{l}\text { Citizenship } \\
\text { Information }\end{array}$ & $\begin{array}{l}\text { Culture and } \\
\text { Language }\end{array}$ \\
\hline $\begin{array}{l}\text { Social Studies } \\
\text { Learning and } \\
\text { Teaching } \\
\text { Approaches }\end{array}$ & $\begin{array}{l}\text { Social Studies } \\
\text { Teaching II }\end{array}$ & $\begin{array}{l}\text { Social Studies } \\
\text { Teaching II }\end{array}$ & $\begin{array}{l}\text { Science and } \\
\text { Research } \\
\text { Ethics }\end{array}$ & $\begin{array}{l}\text { Citizenship } \\
\text { Education }\end{array}$ & & $\begin{array}{l}\text { Turkey's } \\
\text { Human and } \\
\text { Economic } \\
\text { Geography }\end{array}$ \\
\hline $\begin{array}{l}\text { Character and } \\
\text { Value } \\
\text { Education }\end{array}$ & $\begin{array}{l}\text { Local- } \\
\text { Children's } \\
\text { Games in } \\
\text { Social Studies } \\
\text { Teaching }\end{array}$ & $\begin{array}{l}\text { General Human } \\
\text { and Economic } \\
\text { Geography }\end{array}$ & $\begin{array}{l}\text { Fundamentals } \\
\text { of Social } \\
\text { Studies }\end{array}$ & $\begin{array}{l}\text { Turkey's } \\
\text { Human and } \\
\text { Economic } \\
\text { Geography }\end{array}$ & & $\begin{array}{l}\text { Media } \\
\text { Literacy }\end{array}$ \\
\hline $\begin{array}{l}\text { Citizenship } \\
\text { Information }\end{array}$ & $\begin{array}{l}\text { Atatürk's } \\
\text { Principles and } \\
\text { History of } \\
\text { Turkish } \\
\text { Revolution I }\end{array}$ & $\begin{array}{l}\text { Disasters and } \\
\text { Disaster } \\
\text { Management }\end{array}$ & $\begin{array}{l}\text { Research } \\
\text { Methods in } \\
\text { Education }\end{array}$ & $\begin{array}{l}\text { Environmental } \\
\text { Education }\end{array}$ & & $\begin{array}{l}\text { Social Studies } \\
\text { Learning and } \\
\text { Teaching } \\
\text { Approaches }\end{array}$ \\
\hline $\begin{array}{l}\text { Human Rights } \\
\text { and Democracy }\end{array}$ & $\begin{array}{l}\text { Social } \\
\text { Anthropology } \\
\text { and History of } \\
\text { Civilizations } \\
\text { Historical }\end{array}$ & $\begin{array}{l}\text { Physical } \\
\text { Geography of } \\
\text { Turkey }\end{array}$ & $\begin{array}{l}\text { Education } \\
\text { Philosophy }\end{array}$ & $\begin{array}{l}\text { Economics and } \\
\text { Innovation }\end{array}$ & & $\begin{array}{l}\text { Globalization } \\
\text { and Society }\end{array}$ \\
\hline $\begin{array}{l}\text { Education } \\
\text { Sociology }\end{array}$ & $\begin{array}{l}\text { Proof, Local } \\
\text { and Oral } \\
\text { History in } \\
\text { Social Studies } \\
\text { Teaching }\end{array}$ & $\begin{array}{l}\text { Political } \\
\text { Geography and } \\
\text { Geopolitics of } \\
\text { Turkey }\end{array}$ & $\begin{array}{l}\text { History of } \\
\text { First Turkish- } \\
\text { Islamic States }\end{array}$ & $\begin{array}{l}\text { Citizenship } \\
\text { Education }\end{array}$ & & \\
\hline $\begin{array}{l}\text { Human } \\
\text { Relationships } \\
\text { and } \\
\text { Communication }\end{array}$ & $\begin{array}{l}\text { Pre-Islamic } \\
\text { Turkish } \\
\text { History and } \\
\text { culture }\end{array}$ & $\begin{array}{l}\text { Citizenship } \\
\text { Information }\end{array}$ & $\begin{array}{l}\text { New and } \\
\text { Modern } \\
\text { History }\end{array}$ & & & \\
\hline \multirow[t]{2}{*}{$\begin{array}{l}\text { Media Literacy } \\
\text { and } \\
\text { Communication }\end{array}$} & $\begin{array}{l}\text { History of } \\
\text { First Turkish- } \\
\text { Islamic States }\end{array}$ & & $\begin{array}{l}\text { History and } \\
\text { Philosophy of } \\
\text { Science }\end{array}$ & & & \\
\hline & $\begin{array}{l}\text { Ottoman } \\
\text { History I-II } \\
\text { New and } \\
\text { Modern } \\
\text { History }\end{array}$ & & & & & \\
\hline
\end{tabular}


Table 5 gives the findings about the correlation of learning areas with lessons on the revised curriculum. As a result of document analysis, based on the findings in relation to the relationship among the lessons on the 2018 social studies teacher training curriculum with topics in the primary and middle school social studies lessons, it is possible to say that of the total of 131 outcomes on the $4^{\text {th }}, 5^{\text {th }}, 6^{\text {th }}$ and $7^{\text {th }}$ class MEB curriculum, 88 can be associated with lessons included in the undergraduate curriculum.

Based on data obtained from documents, it is possible to relate 17 of the 18 outcomes in the 'individual and society' learning area; 17 of the 19 total outcomes in the 'culture and heritage' learning area; 17 of the total 19 outcomes in the 'humans, places and environments' learning area; and 8 of the total 16 outcomes in the 'global connections' learning area.

As a result of document analysis, it was identified that 12 of the 18 outcomes in the 'science, technology and society' learning area could be associated with lesson content on the undergraduate curriculum. In social studies lessons, students should be able to compare the history of technological products and their current uses, classify technological products according to their area of use and describe inventors of technological products they use. The lesson on the undergraduate curriculum which meets these outcomes is 'science, technology and society'. This lesson content comprises developments in science and technology from the past to the present. In relation to this lesson, one lecturer stated;

"There's a science, technology and society lesson. This lesson doesn't go beyond a history lesson, in other words, science, technology and society is a problem on its own. We can still say this. In history this scientist found this, that, the other, the scientific process developed in this way and we reached the present, but we don't explain the present. In other words, I don't know how it should be included in a lesson, I can't conceptualize the name, but like I say if the content to follow technology only stays as science, technology and society, this lesson content should definitely fit the new pattern." (LS5, 28'53")

Document analysis concluded that of the total 23 outcomes in the 'production, consumption and distribution' learning area, 10 were associated with lesson content included in the undergraduate curriculum. A lecturer considering the outcomes for the production, consumption and distribution learning area were not associated with sufficient lessons on the social studies teacher training curriculum stated the following; 
"On the primary school curriculum, production, distribution, consumption is the learning area with most outcomes; however, on the undergraduate curriculum there is only one lesson called economy." (LS7, 05'47")

Based on data obtained from documents, of the total of 18 outcomes belonging to the 'active citizenship' learning area, only 7 were associated with lesson content included in the undergraduate curriculum. In relation to this situation, the following statement was made;

"We say citizenship, but we appear to neglect citizenship. In other words, it's neglected in the social studies teacher training curriculum and neglected on the social studies primary-middle school curricula. As a result, we say cultivate good citizens, we say it's a target of social studies but we neglect the most important topic." (LS2, 37'38")

\section{Findings About Lessons on the 2018 Social Studies Teacher Training Curriculum Fulfilling Competencies Predicted in the Framework of Social Studies Teacher Training Competencies}

With the aim of accessing findings about whether lessons on the 2018 social studies teacher training curriculum achieve the competencies predicted within the framework of social studies teacher training competencies, the 'social studies teacher training competencies' categories was found to have subcategories of 'planning and organizing the teaching process', 'learning and teaching process', 'monitoring and assessment', 'cooperation' and 'ensuring professional development' and codes related to these subcategories were created. 


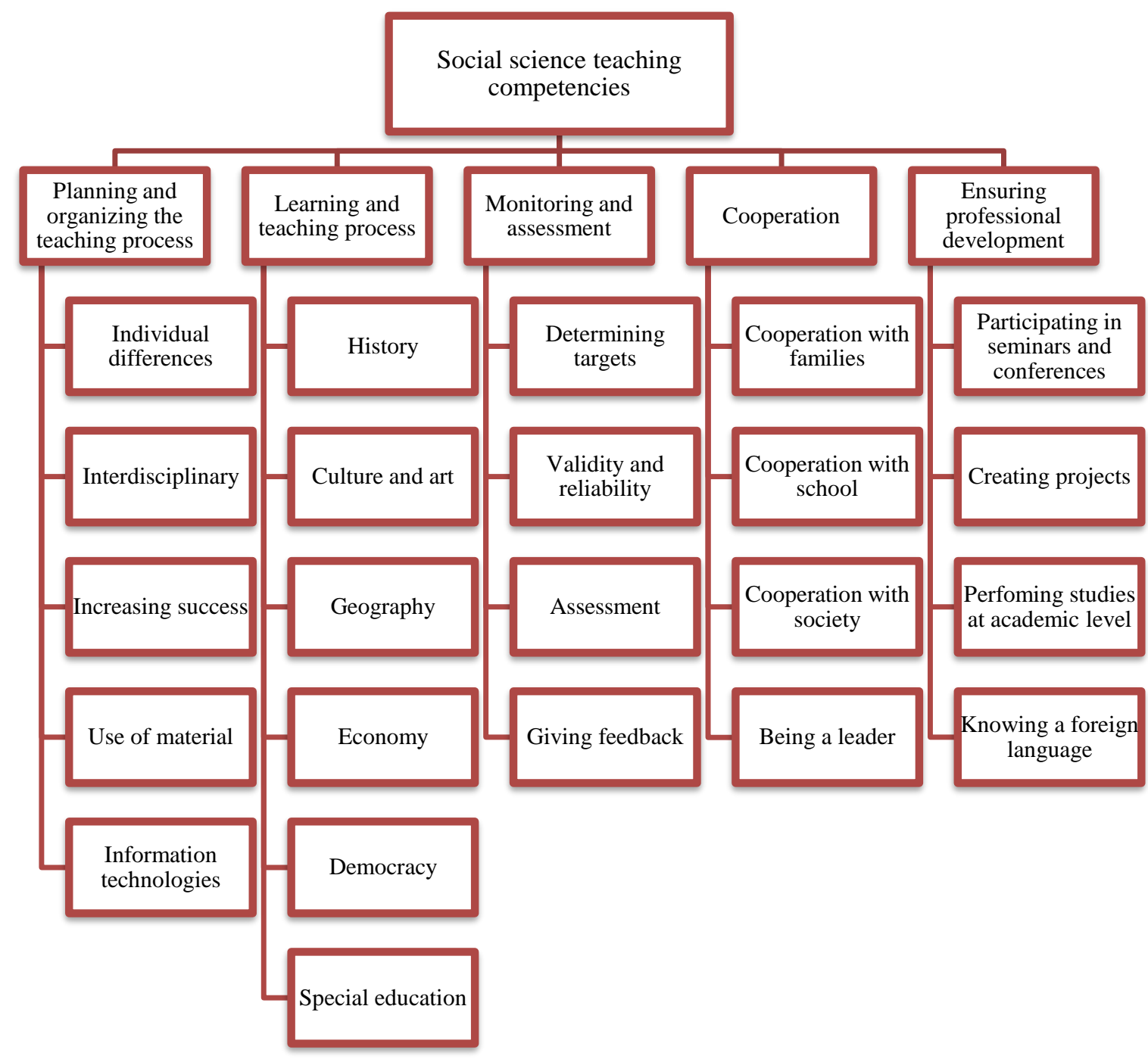

Figure 3. Subcategories and Codes Related to the "Social Studies Teacher Competencies" Category

The subcategories linked to the 'social studies teacher competencies' category and codes related to these subcategories are shown in Figure 3. It can be said that professional information lessons have an important place on the revised program to meet the planning and organization of the teaching process competency. A lecturer drew attention to the importance of individual differences in planning the teaching process and stated the following about the 'education psychology' lesson;

"The education psychology lesson was placed in the $2^{\text {nd }}$ semester of $1^{\text {st }}$ year; I think this lesson is very important because it's associated with many development processes in the learning concept so I don't think preservice teachers will conceptualize the importance of this lesson very quickly during the adaptation process to a new faculty and university. Even if they do grasp this, I think it is 
early to associate these concepts, to bring the virtual points together. In later years, in $2^{\text {nd }}$ year, that's when it was previously. According to me there's nothing logical about putting it in $1^{\text {st }}$ year." (LS7, 23'15")

In relation to the skill of designing material belonging to the planning the teaching process competency, one lecturer stated the following about the 'teaching technologies' lesson;

"The teaching technologies lesson enters the professional information lessons. Which is to say that entering professional information, in fact means the educator, a non-social science person enters social studies lessons. I'm very curious about how someone from another field will teach a teaching technology to be used in social science." (LS5, 45'20")

One of the competences related to planning the teaching process is the use of information technologies, found in the 'information technology' lesson on the undergraduate curriculum. In this lesson the importance of the use of the internet in education and the effects of computers on young people will be dealt with. The following opinion was stated in relation to this lesson;

"You put an information technology lesson, but I don't think we have teachers who can teach an information technology lesson. There is no teacher who can fulfill the content of this training, who has the quality to increase the skills of the students about this topic." (LS3, 32'11')

In terms of fulfilling the competencies of managing the learning and teaching process, the education lessons on the revised curriculum have great importance. A lecturer criticized the topics encompassing learning and teaching processes on the social studies teacher training curriculum as being dominated by history and geography;

\begin{abstract}
"Dealing with history and geography in this much detail and mainly spending the whole of the program on this is a bit problematic, I think. In other words, I think we need to include other areas to develop general culture instead. Because for a teacher to teach children a social event, it is necessary to know that event from many aspects, from historical, philosophical, sociologic and psychologic and then economic and even political. A student graduating from this curriculum will only have accumulated knowledge to be able to evaluate from more a historical and geographic perspective." (LS2, 08'00”)
\end{abstract}

In terms of fulfilling monitoring and assessment competencies, the 'social studies curricula' lesson included on the revised curriculum appears to focus on measurement and assessment 
approaches. The 'social studies teaching II' lesson appears to provide information about techniques used for measurement and assessment applications. The 'measurement and assessment in education' lesson studies concepts like validity, reliability and feedback. The 'morals and ethics in education' lesson appears to focus on ethical principles in learning and assessment processes.

In terms of the topic of cooperation between school, family and society, the content of the 'Turkish education system and school management' lesson is important. The content of this lesson mentions cooperation between school, family and society in the education and teaching process. In relation to this lesson, a lecturer stated the following opinion;

"I still think some lessons were written to give lessons to certain lecturers in certain areas; in other words, there a lesson called Turkish education system and school management for example. Questions should be asked about how functional this lesson is in the teacher training process, how necessary it is. " (LS4, 16'06")

The content of the 'class management' lesson appears to focus on the importance of parentteacher meetings. In relation to this lesson, the following opinion was expressed;

"There's a lesson called class management, this very important lesson is an area which teachers should know very well. But this lesson is perceived as a lesson given by experts in education management, I see the continuous encouragement of this perception as very meaningless and problematic." (LS4, 16'31')

Similarly, the content of the 'special education and inclusion' lesson appears to mention the importance of family participation in education and cooperation with families. In relation to this lesson, the following opinion was expressed;

"For example, there was no special education for us in the past and inclusive education in schools remained so difficult and students, we all experienced difficulties. Then special education came and we all relaxed." (LS10, 16'13")

It is possible to say that the general culture lessons have an important place in the curriculum to fulfill the competency of ensuring professional development. To ensure preservice teachers have the ability to perform studies in relation to the field at academic level, the undergraduate curriculum includes 'Turkish language I-II' and 'research methods in education' lessons. In relation to this a lecturer stated; 


\begin{abstract}
"I gave the students homework and I wanted them to complete their homework as reports. I looked at the homework and it was a disaster; in other words, homework with the quality of a primary school, or I don't know, middle school student. Why was it all copy and paste for one? No student had gained any scientific quality. Whereas they had set the preparation criteria for the homework themselves, in other words you will write homework with the value of a scientific report, write the report in accordance with techniques in the scientific research methods lesson, there were criteria about whatever ethical writing rules. I said why did you do this? One said, up to today we gave teachers asking for reports empty CDs and got 100 points..." (LS3, 26'15")
\end{abstract}

One of the competencies in the social studies field is the need to know at least one foreign language. To fulfill this competency, teacher training programs include a 'foreign language' lesson. In relation to the mandatory general culture lesson on the curriculum, a lecturer stated the following opinion;

"If I have to teach another person coming to university the Atatürk's principles and History of Turkish Revolution let's not teach it, it will be better. If I'm still trying to teach their main language, it's better so let's not teach it. If I try to teach information technologies in this semester, again, let's not. If we can't solve a foreign language in 2 hours per week there's no logic in doing it for 3 hours. But in the context of the constitution, you have to put it in mandatory lessons." (LS8, 24'58')

\title{
Discussion and Conclusion
}

When the 2018 social studies teacher training curriculum is investigated, it appears some lessons were removed and other new lessons added, while some lessons only had names or semesters changed. In this way, it can be said the changes to the revised social studies teacher training curriculum were experienced in one dimension of the curriculum development process; content. Data obtained from interviews with lecturers contributing to the preparation of the curriculum have characteristics which support this finding.

The 'school experience' lesson removed from the social studies teacher training curriculum was found to be important by lecturers as it gave preservice teachers the opportunity to know their profession and opinions were stated about the need to include it in the first semester of the curriculum. Research by Tural (2018) revealed the 'school experience' lesson allowed 
preservice teachers the opportunity to gain experience about the profession. Lecturers participating in this research had positive attitudes to the 'drama' lesson and appeared to think this lesson should not have been removed from the curriculum. When research by Başc1 and Gündoğdu (2011) is examined, it was identified that preservice teachers had positive attitudes in relation to the 'drama' lesson. The 'geography of countries' lesson removed from the curriculum was among lessons criticized by lecturers. Research results by Öztürk and Günel (2016) from Eskişehir province revealed that teachers had insufficient preliminary information about this lesson and recommended the need for teacher training programs to provide education to train preservice teachers with a global viewpoint. Research by Acun, Yücel, Belenkuyu, \& Keleş (2017) identified that the aims of social media use by university students changed linked to a variety of variables and they lacked confidence in social media. In this context, the 'media literacy' lesson added to the program can be said to provide benefit to preservice teachers about the effective and safe use of social media. Research results by Deveci and Çengelci (2008) were observed to include the recommendation to add a 'media literacy' lesson to teacher training curricula.

The lecturers participating in this research stated lessons in faculties are not carried out in accordance with the constructivist approach. Research by Ateş, Çetinkaya Özdemir and Taneri (2019) stated that preservice class teachers did not receive education in accordance with the constructivist teaching model and that lessons were carried out according to traditional methods. Lecturers contributing to preparation of the revised social studies teacher training curriculum stated that as year level increased, the motivation of preservice teachers decreased. In parallel with this result, quantitative research investigating motivation related to the teaching profession by preservice social studies teachers by Recepoğlu and İbret (2019) identified that as class level increased the motivation of preservice teachers for the teaching profession lowered. According to quantitative research results by Gündoğdu, Çimen and Turan (2008) investigating preservice teacher opinions with a survey, they concluded that as class level increased, exam stress increased.

This study was carried out with the aim of investigating the revised social studies teacher training curriculum revealed that the problems present in the transformation process of a theoretically organized curriculum into implementation continued. Research results by Yapic1 and Demirdelen (2007) identified differences of opinion among teachers about the 
applicability of the social studies curriculum. In light of findings obtained in the research, the following recommendations are made for policy-makers and researchers.

\section{Recommendations}

- Environments should be created to ensure exchange of ideas between people responsible for the curriculum development process in the future.

- Before implementing the developed curriculum, it will be beneficial to carry out pilot studies and evaluate the results.

- In future curriculum development processes, importance should be given to the learning and teaching process and measurement and assessment dimensions, in addition to the content dimension of the curriculum.

- The effect of lecturers giving lessons in the process of developing competencies in terms of profession of preservice social studies teachers is great. Studies should be performed which would reveal the quality of lecturers giving lessons in social studies teacher training undergraduate departments.

- According to the data obtained in this study, one of the problems affecting the learning and teaching processes is motivation. Studies should be performed about how to resolve factors lowering motivation of preservice social studies teachers towards the teaching profession. 


\section{References}

Acun, İ., Yücel, C., Belenkuyu, C., \& Keleş, S. (2017). Üniversite öğrencilerinin sosyal medya kullanım amaçlarının incelenmesi. Kuram ve Uygulamada Eğitim Yönetimi Dergisi, 23(4), 559-602. doi: 10.14527/kuey.2017.018

Acun, İ., Yücel, C., Önder, A., \& Tarman, B. (2013). Değerler: Kim ne kadar değer veriyor?. Uşak Üniversitesi Sosyal Bilimler Dergisi, 6(1), 180-197.

Akbaba, S. (2006). Eğitimde motivasyon. Atatürk Üniversitesi Kazım Karabekir Ĕ̆gitim Fakültesi Dergisi, 13, 343-361.

Akbaş, O. (2008). Değer eğitimi akımlarına genel bir bakış. Değerler Eğitimi Dergisi, 6(16), 9-27.

Akdağ, H. (2008). Ilköğretim 6. ve 7. sınıf sosyal bilgiler öğretim programının öğretmen ve ögrenci açısından uygulama dönütleri (Konya ili örneği) (Unpublished doctoral dissertation). Gazi University, Ankara.

Akdemir, A. S. (2013). Türkiye'de öğretmen yetiştirme programlarının tarihçesi ve sorunlar1. Electronic Turkish Studies, 8(12), 15-28.

Artvinli, E. (2010). Coğrafya derslerini yapılandırmak: Aksiyon (eylem) araştırmasına dayalı bir ders tasarım1. Marmara Coğrafya Dergisi, 21, 184-218.

Ateş, S., Çetinkaya Özdemir, E., \& Taneri, A. (2019). İstenmeyen öğretmen davranışlarına ilişkin öğretmen adaylarının görüşleri. Bolu Abant İzzet Baysal Üniversitesi Eğitim Fakültesi Dergisi, 19(1), 37-56. doi: 10.17240/aibuefd

Azar, A. (2011). Türkiye'deki öğretmen eğitimi üzerine bir söylem: Nitelik mi, nicelik mi. Yükseköğretim ve Bilim Dergisi, 1(1), 36-38.

Başçı, Z., \& Gündoğdu, K. (2011). Öğretmen adaylarının drama dersine ilişkin tutumları ve görüşleri: Atatürk üniversitesi örneği. İlköğretim Online, 10(2), 454-467.

Can, Ş. (2013). Tezsiz yüksek lisans öğrencilerinin öğretmenlik mesleğine yönelik tutumları. Sosyal ve Beşeri Bilimler Araştırmaları Dergisi, 24, 13-28.

Çelik, D. (2011). Illköğretim okul yöneticilerinin sahip olması gereken vizyoner liderlik özelliklerine ilişkin ögretmen görüşleri (Unpublished master's thesis). Eskişehir Osmangazi University, Eskişehir. 
Çelik, M., \& Gündoğdu, K. (2007). Türkiye'de okul öncesi eğitimin tarihsel gelişimi. Atatürk Üniversitesi Kazım Karabekir Eğitim Fakültesi Dergisi,16, 172- 190.

Çelikten, M., Şanal, M., \& Yeni, Y. (2005). Öğretmenlik mesleği ve özellikleri. Erciyes Üniversitesi Sosyal Bilimler Enstitüsü Dergisi, 1(19), 207-237.

Demir, S. (2012). Eğitim fakülteleri programı kapsamında yer alan öğretmenlik meslek bilgisi derslerinden "öğretim ilke ve yöntemleri" dersinin değerlendirilmesi (Unpublished master's thesis). Gazi University, Ankara.

Demirel, Ö. (2007). Eğitimde program geliştirme. Ankara: Pegem A.

Deveci, H., \& Çengelci, T. (2008). Sosyal bilgiler öğretmen adaylarından medya okuryazarlığına bir bakış. Yüzüncü Yll Üniversitesi Eğitim Fakültesi Dergisi, 5(2), 25-43.

Duman, T. (2009). Türkiye'de öğretmen yetiştirme ve sorunları. Türk Yurdu Dergisi, 262, $32-35$.

Gökçe, E. (1999). İlkögretim öğretmenlerinin yeterlikleri (Unpublished doctoral dissertation). Ankara University, Ankara.

Gülcan, M. G., \& Taner, N. (2011). Öğretmen görüşlerine göre ilköğretimde ev ziyaretinin okul başarısına etkisi (Kahramanmaraş il örneği). Mehmet Akif Ersoy Üniversitesi Eğitim Fakültesi Dergisi,22, 129-144.

Gündoğdu, K., Çimen, N., \& Turan, S. (2008). Öğretmen adaylarının kamu personeli seçme sınavına (KPSS) ilişkin görüşleri. Ahi Evran Üniversitesi Kırşehir Eğitim Fakültesi Dergisi, 9(2), 35-43.

Hayırsever, F. (2010). Sosyal bilgiler ders, öğretmen kılavuz ve öğrenci çalışma kitaplarının sosyal bilgiler öğretim programında kazandırılması hedeflenen temel beceriler açısından değerlendirilmesi (Unpublished doctoral dissertation). Ankara University, Ankara.

İnci, S. (2009). Türkiye sosyal bilgiler programının karşılaştırmalı incelenmesi (Kanada(Ontorio), Irlanda, ABD (Newyork, Kaliforniya), Finlandiya, Yeni Zelanda) (Unpublished master's thesis). Kocaeli University, Kocaeli.

Kabapınar, Y. (2014). Kuramdan uygulamaya sosyal bilgiler öğretimi. Ankara: Pegem. 
Kartal, S. (2008). Toplum kalkınmasında farklı bir eğitim kurumu: Köy Enstitüleri. Mersin Üniversitesi Eğitim Fakültesi Dergisi, 4(1), 23-36.

Kavcar, C. (2002). Cumhuriyet döneminde dal öğretmeni yetiştirme. Ankara Üniversitesi Eğitim Bilimleri Fakültesi Dergisi, 35(1-2), 1-14.

Kılınçkaya, Ö. (2018). Sosyal bilgiler öğretmenlerinin Türkiye’deki sosyal bilgiler eğitimine ilişkin görüşleri (Unpublished Master’s Thesis). Uşak University, Uşak.

Kızıltepe, Z. (2002). İyi ve etkili öğretmen. Eğitim ve Bilim, 27(126), 10-14.

Koçak, A., \& Arun, Ö. (2006). İçerik analizi çalışmalarında örneklem sorunu. Selçuk İletişim, 4(3), 21-28.

Koçak, S, \& Kavak, Y. (2014). Milli Eğitim Bakanlığı'nın öğretmen atama esasları ve kaynak yükseköğretim programlarıyla ilgili gelişmeler. Hacettepe Üniversitesi Ĕ̈itim Fakültesi Dergisi, 29(4), 157-170.

Korkmaz, Ö. (2009). Eğitim fakültelerinin öğrencilerin eleştirel düşünme eğilim ve düzeylerine etkisi. Türk Ĕ̆itim Bilimleri Dergisi, 7(4), 879-902.

Kutluca, T., Birgin, O., \& Çatlıŏlu, H. (2007). Öğretimde planlama ve değerlendirme dersi uygulama etkinliklerinin öğretmen adaylarına sağladığı faydalar. Uluda ̆̆ Üniversitesi Eğitim Fakültesi Dergisi, 20(1), 89-110.

Milli Eğitim Bakanlı̆̆1 (2017). İlköğretim özel alan yeterlilikleri (sosyal bilgiler ögretmenliği). Retrieved July 20, 2018, from https://oygm.meb.gov.tr.

Milli Eğitim Bakanlığı (2018). Sosyal bilgiler dersi öğretim programı (ilkokul ve ortaokul 4, 5, 6 ve 7. siniflar). Retrieved October 18, 2018, from http://mufredat.meb.gov.tr.

Özdaş, F. (2013). Ortaokullarda dĕgerler eğitimi ve istenmeyen ögrenci davranışlarına ilişkin öğretmen görüşlerinin değerlendirilmesi (Unpublished doctoral dissertation). Firat University, Elazı̆̆.

Öztürk, C. (2012). Sosyal bilgiler öğretimi: demokratik vatandaşlık eğitimi. In C. Öztürk (Ed.), Sosyal Bilgiler Öğretimi: Demokratik Vatandaşlık Ĕ̆itimi (pp. 1-31). Ankara: Pegem Akademi. 
Öztürk, F., \& Günel, E. (2016). Sosyal bilgiler öğretmenlerinin küresel sistem, küresel eğitim ve çeşitlilik kavramlarına ilişkin algısı. Illköğretim Online, 15(1), 172-185. doi: https://doi.org/10.17051/io.2016.79798

Öztürk, M. K. (2009). Sosyal bilgiler öğretmenlerinin okul, aile ve toplum ilişkileri yeterlik alanına ilişkin görüşleri ve öz değerlendirmeleri. Bilig-Türk Dünyası Sosyal Bilimler Dergisi, 49, 113-126.

Recepoğlu, S., \& İbret, B. Ü. (2019). Sosyal bilgiler öğretmen adaylarının öğretmenlik mesleğine yönelik motivasyonlarının incelenmesi. Tarih Kültür ve Sanat Araştırmaları Dergisi, 8(1), 320-331.

Saç, C. (2016). 2002-2014 yılları arasında öğretmen yetiştirme ve atama politikalarının değerlendirilmesi (Unpublished master's thesis). Atatürk University, Erzurum.

Şenyurt, S. (2016). Eğitimde ölçme ve değerlendirme alanında yapılan yüksek lisans tezlerinin tematik ve metodolojik açıdan incelenmesi (Unpublished master's thesis). Gaziantep University, Gaziantep.

Şimşek, H. (2017). Eğitim sisteminde öğretmenin rolü ve öğretmenlik mesleği. In H.B. Memduhoğlu \& K. Yılmaz (Eds.), Eğitim Bilimine Giriş (pp. 251-275). Ankara: Pegem Akademi.

Tural, A. (2018). Sosyal bilgiler öğretmen adaylarına göre okul deneyimi dersinin ögretmenlik mesleğine etkisi (Unpublished master's thesis). Amasya University, Amasya.

Yapıc1, M., \& Demirdelen, C. (2007). İlköğretim 4. sınıf sosyal bilgiler öğretim programına ilişkin öğretmen görüşleri. İlköğretim Online, 6(2), 204-212.

Yıldırım, A. (1999). Nitel araştırma yöntemlerinin temel özellikleri ve eğitim araştırmalarındaki yeri ve önemi. Eğitim ve Bilim, 23(112), 7-17.

Yılmaz, B. (2005). Öğretmenlik nasıl bir meslektir?. In A. Murat Sümbül (Ed.), Öğretmenin Dünyası (pp. 7-22). Ankara: Mikro.

Yükseköğretim Kurumu Başkanlığ1 (2018). Eğitim fakültesi öğretmen yetiştirme lisans programları. Retrieved October 27, 2018, from https://www.yok.gov.tr. 